\title{
IMMOBILIZATION OF CLEA-LIPASE OF Hevea brasiliensis ONTO MAGNETIC NANOPARTICLES FOR ENHANCED BIOCATALYTIC PERFORMANCE
}

\author{
NUR AMALIN AB AZIZ AL SAFI and FARIDAH YUSOF* \\ Department of Biotechnology Engineering, Kulliyyah of Engineering, \\ International Islamic University Malaysia, P.O. Box 10, 50728 Kuala Lumpur, Malaysia \\ "E-mail:yfaridah@iium.edu.my
}

Accepted 26 May 2020, Published online 30 June 2020

\begin{abstract}
Skim latex from Hevea brasiliensis consists of many useful proteins and enzymes that can be utilized to produce value-added products for industrial purposes. In this project, to enhance the properties of the recovered lipase from skim latex serum, this enzyme was immobilized via cross-linked enzyme aggregates (CLEA) technology, and supported by magnetic nanoparticles (MNP-CLEA-lipase). MNP-CLEA-lipase was prepared by chemical cross-linking of enzyme aggregates with amino functionalized MNP, which can easily be separated from the spent media after use by magnetic field. The performances of the newly produced MNP-CLEA-lipase were compared with its unsupported counterpart, CLEA-lipase. The optimum conditions for the preparation of CLEA-lipase was carried out by using $45 \%$ saturated $\left(\mathrm{NH}_{4}\right)_{2} \mathrm{SO}_{4}$ and 50 mM glutaraldehyde (GA), whereas for MNP-CLEA-lipase, it was carried out by using $70 \%$ saturated $\left(\mathrm{NH}_{4}\right)_{2} \mathrm{SO}_{4}$ and $60 \mathrm{mM}$ GA. The optimum $\mathrm{pH}$ changes from 6 to 8 when CLEA-lipase is supported, while achieving a maximum of $69.92 \%$ residual activity (RA) compared to $20.66 \%$ for the unsupported CLEA-lipase. However, the optimum temperature for both are the same $\left(35^{\circ} \mathrm{C}\right)$, with MNP-CLEA-lipase achieving $85.89 \%$ RA compared to $31.91 \%$ for the unsupported ones. Stability studies carried out on both showed that MNP-CLEA-lipase has higher thermal $\left(25-60^{\circ} \mathrm{C}\right)$ and $\mathrm{pH}(5-10)$ stabilities compared to its unsupported counterparts. As for the reusability of enzymes, MNP-CLEA-lipase retained $56.46 \%$ of residual activity after six cycles of reuse. The FESEM results showed that the MNP-CLEA-lipase is a Type 2, which is less structured, and this has bearings towards its activities. FTIR analysis showed the presence of Amide I and Amide II bands in MNP-CLEA-lipase, originating from the newly formed cross-linked between the silanized MNP and CLEA-lipase. Overall, MNP supported CLEA-lipase showed better performance compared to the unsupported biocatalyst.
\end{abstract}

Key words: Skim latex, Skim latex serum, Hevea brasiliensis, CLEA-lipase, magnetite, magnetic nanoparticles (MNPs), MNP-CLEA-lipase

\section{INTRODUCTION}

The major source of natural rubber (NR) is from Hevea brasiliensis rubber plant. South East Asian countries contribute to $92 \%$ of the worldwide NR production, and Malaysia stands as the world's fifth largest producer. Malaysia supplies quality raw rubber of Standard Malaysian Rubber (SMR) grades. This country also produces high quality rubber products such as medical gloves and automotive components (Cataldo, 2000).

Upon tapping, latex exuded from the plant is treated with ammonia to avoid coagulation, however this process leads to the dilution of latex samples. The ammoniated latex is then centrifuged to improve the dry rubber content (DRC) to about $70 \%$, to obtain high concentrated latex for use in the latex-based industries. Centrifugation produces aqueous byproduct, and this is separated from the concentrated rubber portion and discarded into the environment (Mohammadi et al., 2013; Mohamed \& Yusof, 2014). This aqueous part, termed skim latex, is deemed to be one of the most polluting wastes in the rubber industry due to its viscosity as well as the strong ammoniated smell. To avoid pollution, skim latex is usually pretreated in the effluent treatment oxidation pond before the cleaner water is released into the main waterways (Mohamed \& Yusof, 2014).

\footnotetext{
* To whom correspondence should be addressed.
} 
Skim latex still has some amount of rubber particles, at about $4 \%$ to $8 \%$ DRC (George et al., 2009). By centrifugation, skim latex is separated into skim rubber and skim latex serum. Skim latex serum is the main composition of skim latex, which contains more than $75 \%$ of the total soluble protein (Rattanaphan et al., 2012). These hundreds of protein, whereby some of them are enzymes, are waiting to be discovered and identified. Hydrolases are some of the enzymes found in skim latex serum (Yusof et al., 2013; Mardina \& Yusof, 2018). According to Yusof et al. (2016), hydrolases are easy to use and do not require cofactors, which is one of the reasons why they are frequently used in industries such as food manufacturing (Aravindan et al., 2007; Undurraga et al., 2011), detergents (Rathi et al., 2001; Sarkar et al., 2012; Emtenani et al., 2013; Hasan et al., 2013), pharmaceuticals (Chen \& Tsai, 2000; Xin et al., 2001; GotorFernandez et al., 2006), and biodiesel production (Dussan et al., 2007; Raita et al., 2010; Abdelmoez et al., 2013; Stergiou et al., 2013). Lipid acyl hydrolase enzyme (LAH), a subtype of lipase, has been recovered from the serum (Yusof et al., 1998; Mohamed \& Yusof, 2014). The recovered lipase was successfully immobilized via cross-linked enzyme aggregates (CLEA) technology (Yusof et al., 2013), a carrier-free immobilization enzyme technique for biocatalysis (Sheldon, 2007a; Sheldon; 2007b; Roessl et al., 2009; Brady \& Jordaan, 2009; Mahmod et al., 2015; Khanahmadi et al., 2015; Yusof et al., 2016; Mahmod et al., 2016; Sheldon, 2019). CLEA preparation involves protein precipitation using precipitant, such as ammonium sulphate, $\left(\mathrm{NH}_{4}\right)_{2} \mathrm{SO}_{4}$, followed by cross-linking with polyfunctional reagent, such as glutaraldehyde (GA) (Sheldon, 2007a; Sheldon; 2007b; Yusof et al., 2013; Talekar et al., 2013; Yusof et al., 2016; Sheldon, 2019). CLEA technique combines purification and immobilization into a single operation to provide highly stable and recycleable catalysts with remarkable catalytic efficiency (Sheldon, 2007a; Sheldon, 2007b; Sheldon, 2011; Sheldon \& Van Pelt, 2013; Talekar et al., 2013; Gupta et al., 2013a; Barbosa et al., 2014; Sheldon, 2019).

Nanoparticles have long been used to immobilize enzymes due to its significant surface properties (Ansari \& Hussain, 2012), but the application of these nanosupports is limited due to problems with recovery, e.g., via centrifugation or filtration. However, the problem could be solved by using magnetic nanoparticles (MNPs), whereby, enzymes attached to MNPs can be easily separated from the reaction media by using a magnet. MNPs have been commonly used for enzyme immobilization in recent years due to this practical advantage and their low toxicity (Khoshnevisan et al., 2017). Besides single enzymes, CLEAs have also been shown to be successfully supported by MNPs. This 'smart', magnetic CLEA is prepared by adding aminofunctionalized magnetite nanoparticles into the enzyme solution. The enzyme is precipitated to form aggregates and in the presence of a cross-linker, it cross-linked with nanoparticles (Reza et al., 2010; Ansari \& Husin, 2012; Talekar 2012; Gupta et al., 2013b; Bhattacharya \& Pletschke, 2014; Elkady et al., 2016; Gupta et al., 2017). Besides the ease of separation, many researchers have also reported on the higher recovery of enzymatic activity once supported by MNPs (Reza et al., 2010; Ansari \& Husin, 2012; Talekar 2012; Gupta et al., 2013b; Bhattacharya \& Pletschke, 2014; Elkady et al., 2016; Gupta et al., 2017).

CLEA-lipase has been produced from the skim latex of Hevea brasiliensis by Yusof et al. (2013). However it has shown a remarkable loss in activity when compared to its free enzyme system; however, the enhanced stability and recyclability of this cleated biocatalyst compensates for the decreased activity. This project mainly aims at developing a more robust and activity enhanced biocatalyst by producing MNP-CLEA-lipase from skim latex of Hevea brasiliensis. The residual activity of MNPCLEA-lipase was compared to CLEA-lipase. The effects of the concentrations of $\left(\mathrm{NH}_{4}\right)_{2} \mathrm{SO}_{4}$ (as precipitant) and GA (as cross-linker) on the immobilized enzymes, optimum temperature and $\mathrm{pH}$, thermal and $\mathrm{pH}$ stabilities, reusability of both immobilized enzymes were compared. The newly produced MNP-CLEA-lipase was submitted for structural characterisation and morphology analysis via FTIR and FESEM respectively.

\section{MATERIALS AND METHODS}

\section{Materials}

The skim latex of Hevea brasiliensis was obtained from the MARDEC Industrial Latex Sdn. Bhd. in Tapah, Perak, Malaysia. All chemicals used for this project were of analytical grade.

\section{Methods}

\section{Preparation of skim latex serum}

To encourage the coagulation of rubber, glacial acetic acid was added to skim latex to reduce the $\mathrm{pH}$ from 10 to 5 . The sample was then centrifuged at $10,000 \mathrm{rpm}$ at $4^{\circ} \mathrm{C}$ for $30 \mathrm{~min}$ to separate coagulated rubber (skim rubber) from the supernatant, skim latex serum. Skim rubber was discarded and the serum was pooled. Solid $\left(\mathrm{NH}_{4}\right)_{2} \mathrm{SO}_{4}$ was then added to the supernatant until it reached $4 \mathrm{M}$ concentration (or saturation point), and the mixture was left to precipitate overnight 
under slow stirring at $4^{\circ} \mathrm{C}$. The formation of white precipitate was observed and upon centrifugation at 5,000 rpm for $15 \mathrm{~min}$, the precipitate was collected, while the supernatant was discarded. The precipitate was dissolved in minimal phospate buffer saline (PBS) at $\mathrm{pH} 7$ to yield crude enzyme extract or 'free enzyme'. The protein concentration and lipase activity of the free enzyme were determined (Mohamed \& Yusof, 2014).

\section{Preparation of amino-functionalized magnetic nanoparticles}

$\mathrm{NH}_{4} \mathrm{OH}$ was added into a mixed solution of $1.351 \mathrm{~g}$ of $\mathrm{FeCl}_{3} \cdot 6 \mathrm{H}_{2} \mathrm{O}$ and $0.6852 \mathrm{~g}$ of $\mathrm{FeSO}_{4} \cdot 7 \mathrm{H}_{2} \mathrm{O}$ in $25 \mathrm{~mL}$ deionized water at room temperature until a precipitate formed. To remove the residual ions, the precipitate was centrifuged and washed several times with deionized water until it reached $\mathrm{pH} 7$. The precipitate or the magnetic nanoparticles (MNPs) was dried at $100^{\circ} \mathrm{C}$ for $3 \mathrm{~h}$ (Reza et al., 2010; Talekar et al., 2012). The surface of the particles were coated with (3-aminopropyl) trimethoxysilane (APTES) by silanization reaction to obtain aminofunctionalized MNPs. Silanization reaction involved dissolving $1 \mathrm{~mL}$ of APTES, $2 \mathrm{~g}$ of MNPs and $0.25 \mathrm{~mL}$ of deionized water in $25 \mathrm{~mL}$ of methanol. The mixture was sonicated for $30 \mathrm{~min}$. Glycerol of $15 \mathrm{~mL}$ was then added to the mixture, and the solution was incubated in an incubator shaker at $80^{\circ} \mathrm{C}$ for $6 \mathrm{~h}$ at $200 \mathrm{rpm}$. The precipitate obtained was washed with water and methanol for three times in each case, and dried, yielding a fine amino functionalized magnetic powder (Reza et al., 2010; Talekar et al., 2012).

\section{Preparation of CLEA-lipase and MNP-CLEA- lipase}

CLEA-lipase was prepared by pipetting $1.0 \mathrm{~mL}$ of crude enzyme extract containing $1.175 \mathrm{mg} / \mathrm{mL}$ of protein, with a lipase activity of $0.008 \mathrm{U} / \mathrm{mL}$, into a $15 \mathrm{~mL}$ Falcon tube. $\left(\mathrm{NH}_{4}\right)_{2} \mathrm{SO}_{4}(1.8 \mathrm{~mL})$ and $1 \mathrm{M}$ of GA $(0.2 \mathrm{~mL})$ were added simultaneously to the enzyme solution, and phosphate buffer saline (PBS) was used to make a final volume of $4 \mathrm{~mL}$. The solution was agitated at $200 \mathrm{rpm}$ for $17 \mathrm{~h}$ at room temperature. Then, $3 \mathrm{~mL}$ of water was added to the solution and centrifuged at 4,000 rpm for $30 \mathrm{~min}$ at $4^{\circ} \mathrm{C}$. The supernatant was decanted and the residue was washed three more times with water, centrifuged and decanted. The final CLEA-lipase preparation was kept in $5 \mathrm{~mL}$ of water (Yusof et al., 2013).

MNP-CLEA-lipase was prepared by mixing 20 $\mathrm{mg}$ of aminofunctionalized MNPs with $1.0 \mathrm{~mL}$ of crude enzyme extract. Then, $2.8 \mathrm{~mL}$ of $\left(\mathrm{NH}_{4}\right)_{2} \mathrm{SO}_{4}$ was added to $0.12 \mathrm{~mL}$ of $2 \mathrm{M}$ of GA and finally PBS was used to make a final volume of $4 \mathrm{~mL}$. The solution was agitated at $200 \mathrm{rpm}$ for $17 \mathrm{~h}$ at room temperature. Water $(3 \mathrm{~mL})$ was then added to the mixture and the supernatant was pipetted out and this was repeated twice. Each time, a magnet was used to separate the magnetic biocatalyst from the washings. The final MNP-CLEA-lipase preparation was kept in $5 \mathrm{~mL}$ of water (Talekar et al., 2012).

\section{Protein assay}

Protein assay was conducted according to the standard procedure by Bradford (1976). The dye reagent was prepared by diluting one part of dye reagent concentrate with four parts distilled, deionized water. The dye was filtered through the a Whatman \#1 filter paper to remove particulates. A series of five dilutions of a protein standard was prepared. The linear range of the assay for bovine serum albumin (BSA) is 0.1 to $1.0 \mathrm{mg} / \mathrm{mL}$. One hundred $\mu \mathrm{L}$ of each standard and sample solution was pipetted into clean, dry Falcon tubes. Protein solutions was assayed in triplicates. Five $\mathrm{mL}$ of diluted dye reagent was added to each tube and vortexed. The tubes were incubated at room temperature for $5 \mathrm{~min}$. Then, the absorbance of the assay was measured at $595 \mathrm{~nm}$ using Thermo Scientific Multiskan Go Spectrophotometer (BioRad, 2010). The protein content was calculated based on Eq. (1):

$$
y=1.8105 x+0.5484
$$

where, $y$ represents the absorbance reading and $x$ represents the amount of protein content $(\mathrm{mg} / \mathrm{mL})$.

\section{Lipase enzyme activity assay}

The substrate stock solution was prepared by dissolving $28 \mathrm{mg}$ of $p$-nitrophenyl palmitate ( $p$ NPP) in $100 \mathrm{~mL}$ of $1 \%(\mathrm{v} / \mathrm{v})$ Triton $100-\mathrm{X}$ and $1.7 \mathrm{~mL}$ of $1 \%(\mathrm{w} / \mathrm{v})$ sodium dodecyl sulphate, with stirring and heating. To start the reaction, $1 \mathrm{~mL}$ of $p$ NPP stock solution was incubated with $1 \mathrm{~mL}$ of $0.1 \mathrm{M}$ Tris- $\mathrm{HCl}$ at $\mathrm{pH} 8.2$ and $1 \mathrm{~mL}$ of enzyme (or if in the CLEA form, CLEA was suspended in $1 \mathrm{~mL}$ PBS) in water bath for $30 \mathrm{~min}$ at $37^{\circ} \mathrm{C}$. $\mathrm{NaOH}(1 \mathrm{~mL}$ of $1 \mathrm{M})$ was added to stop the reaction. The absorbance of the assay was measured at $410 \mathrm{~nm}$ using Thermo Scientific Multiskan Go Spectrophotometer and the amount of $p$-nitrophenol released was measured using the standard calibration curve, constructed using $p$-nitrophenol. One unit (U) of lipase enzyme activity is defined as the amount of enzyme required to release $1.0 \mu \mathrm{mol}$ of $p$-nitrophenol per minute under the assay conditions. Lipase activity of free enzyme was calculated using Eq. (2).

$$
\text { Lipase activity }\left(\frac{U}{m L}\right)=\frac{\begin{array}{c}
(\text { Absorbance at } 410 \mathrm{~nm}) \times \\
\text { Total volume of assay }(\mathrm{mL})
\end{array}}{\begin{array}{c}
\text { volume of used enzyme }(\mathrm{mL}) \times \\
\text { Time of assay }(\min ) \times \\
\text { slope of calibration curve }
\end{array}}
$$


Residual activity (\% RA) was used to report for the lipase activity upon immobilization by CLEA technology and it was calculated by using Eq. (3):

$\begin{aligned} & \text { Residual Activity } \\ & \text { of Lipase (\%) }\end{aligned}=\frac{\begin{array}{c}\text { Activity of CLEA } \\ \text { immobilized enzyme }\end{array}}{\text { Activity of free lipase }} \times 100 \%$

\section{Effect of preparation parameters on CLEA-lipase and MNP-CLEA-lipase activity}

The effect of various process parameters in the preparation of CLEA was studied using the traditional experimental design of one-factor-at-atime (OFAT) approach. In this study, three important process parameters were selected, namely the amount of MNPs, the concentrations of $\left(\mathrm{NH}_{4}\right)_{2} \mathrm{SO}_{4}$ and glutaraldehyde (GA). For the amount of MNPs, the values tested were varied at $0,2.0,4.0,5.0,6.0$, $8.0,10.0,15.0$ and $20.0 \mathrm{mg}$ in $4 \mathrm{~mL}$ incubation mixture, the concentration of $\left(\mathrm{NH}_{4}\right)_{2} \mathrm{SO}_{4}$ at $0 \%$, $20 \%, 35 \%, 45 \%, 55 \%$ and $70 \%$ saturation and the concentrations of GA at $0,15,25,35,50,65$ and $75 \mathrm{mM}$. Other parameters were kept constant; agitation rate $(200 \mathrm{rpm})$ and incubation time $(17 \mathrm{~h})$ (Yusof et al., 2013; Mahmod et al., 2015; Easa \& Yusof, 2015). The responses were recorded as lipase residual activity (\% RA).

\section{Optimization of preparation parameters for CLEA- lipase and MNP-CLEA-lipase}

The optimization study of the preparation process of CLEA aims at obtaining the best combination of various preparation parameters for maximal lipase activity. In this project, the design of experiments (DOE) was conducted with the aid of Design Expert ${ }^{\circledR}$ (Version 6.0.8) software using face centred central composite design (FCCCD) under the response surface methodology (RSM) approach. The independent variables used were concentrations of $\left(\mathrm{NH}_{4}\right)_{2} \mathrm{SO}_{4}$ and GA, while the lipase residual activity was selected as the response. Other preparation parameters were kept constant, such as, the amount of MNPs $(20 \mathrm{mg})$, agitation rate (200 rpm) and incubation time (17 h). According to the prescribed design, 13 combination runs were conducted, including five replications at the center point. Data obtained from the OFAT study was used to contsruct the DOE. Statistical analysis via ANOVA was used to evaluate the degree of accuracy held by the derived model equations.

\section{Optimum temperature and $\mathrm{pH}$}

Optimum temperature of the CLEA was determined by assessing the lipase residual activity after incubating the mixture in $0.1 \mathrm{M}$ of Tris- $\mathrm{HCl}$ at $\mathrm{pH} 8.2$ at different temperatures $\left(25-60^{\circ} \mathrm{C}\right)$ for 30 min. Optimum $\mathrm{pH}$ was measured by determining the lipase residual activity by incubating CLEA at the optimum temperature at various $\mathrm{pH}$ values $(5-10)$ of Tris-HCL buffer.

\section{Temperature and $\mathrm{pH}$ stabilities}

Temperature stability of CLEA was determined by measuring lipase residual activity after incubating the enzymes without the addition of substrate at temperatures between $25^{\circ} \mathrm{C}$ and $60^{\circ} \mathrm{C}$ at the optimum $\mathrm{pH}$ for $30 \mathrm{~min}$. The temperature of the samples was brought back to room temperature, followed by the addition of substrate and the normal lipase activity assay was conducted.

To find the $\mathrm{pH}$ stability, lipase residual activity of the samples was determined after incubating the enzymes in substrate-free buffer at various $\mathrm{pH}$ values ranging from 5 to 10 at optimum temperature for 30 min. The substrate was then added followed with the normal lipase activity assay.

\section{Reusability test}

The enzyme reusability test was carried out by obtaining the lipase residual activity of CLEA for six consecutive cycles. After the first cycle, CLEA was separated and washed three more times with water before they are stored in $5 \mathrm{~mL}$ water at $4^{\circ} \mathrm{C}$. After $24 \mathrm{~h}, \%$ RA was measured again and the process was repeated for another five times. For comparison, the first cycle is normalized as $100 \%$ and the achievements of the subsequent cycles were calculated based on the activity in the first cycle.

\section{Morphology analysis by FESEM}

The non-functionalized MNPs and MNP-CLEAlipase samples were sent to Crest Nanosolutions (M) Sdn. Bhd. in Puchong, Selangor, for field electron scanning emission microscopy (FESEM) analysis. The FESEM were operated at $1 \mathrm{kV}$ for the MNPs and at $10 \mathrm{kV}$ for MNP-CLEA-lipase. The morphology of the samples were characterized.

\section{Structural characterisation by FTIR}

Non- and functionalized MNPs, MNP-CLEAlipase and free lipase samples were subjected to FTIR analysis at the INHART laboratory, IIUM, Gombak. Appearances of new functional groups were deliberated. The analyses were done at $4 \mathrm{~cm}^{-1}$ resolution and the scans were done in triplicates.

\section{RESULTS AND DISCUSSION}

\section{Effect of preparation parameters on CLEA-lipase and MNP-CLEA-lipase activity}

The effect of three parameters, namely the amount of MNPs, concentrations of $\left(\mathrm{NH}_{4}\right)_{2} \mathrm{SO}_{4}$ and GA, which are regarded as important parameters for the preparation of MNP-CLEA-lipase was 
studied via OFAT. The results, given as lipase residual activity are shown in Figures 1, 2 and 3. Results in Figure 1 showed that the maximum lipase residual activity was achieved by using the highest amount MNPs (20 mg). It is assumed that, if a higher amount of MNP is used, a higher activity can be achieved due to a higher amount of amino group available for cross-linking with CLEA. However, amounts more than $20 \mathrm{mg}$ was not tested due to the limited availability of MNPs. For the concentration of $\left(\mathrm{NH}_{4}\right)_{2} \mathrm{SO}_{4}$, the results in Figure 2 showed a sharp increase of lipase residual activity from up to $35 \%$ but it plateaued slowly as it is increased from 35 to $70 \%$, and maximised at $70 \%$. From the results, it can be inferred that at $35 \%\left(\mathrm{NH}_{4}\right)_{2} \mathrm{SO}_{4}$ saturation, most of the lipase from the solutions has precipitated.

Although more lipase was seemed to be precipitated as $\left(\mathrm{NH}_{4}\right)_{2} \mathrm{SO}_{4}$ was increased, the results suggest that a higher percentage only increase the activity in minimal amount thus of no real advantage.

Lastly, in Figure 3, the results showed that there was a slight dip in lipase residual activity from 0 to $25 \mathrm{mM} \mathrm{GA}$, but increased sharply as it progressed from 25 to $65 \mathrm{mM}$. From $65 \mathrm{mM} \mathrm{GA}$, the lipase residual activity increased gently and maximized at the highest GA tested, that is at $75 \mathrm{mM}$. It is expected that the residual activity can even go higher by using more than $75 \mathrm{mM} \mathrm{GA}$, however, it was not tested in our research. GA acted as the crosslinker in this system by providing the carboxyl groups to react with the amino functionalised MNPs and the amino groups on CLEA. The maximal values in the three parameters tested were considered when preparing the DOE of the following optimization experiments.

\section{Optimizing the preparation conditions of CLEA}

In this study, the preparation conditions of both CLEA-lipase and MNP-CLEA-lipase were optimized. Due to the limitation of resources, only two parameters were chosen, namely the concentrations of $\left(\mathrm{NH}_{4}\right)_{2} \mathrm{SO}_{4}$ and $\mathrm{GA}$, while keeping the agitation rate at $200 \mathrm{rpm}$ and stirring time for $17 \mathrm{~h}$. As for the supported CLEA, functionalized MNPs were kept constant at $20 \mathrm{mg}$ in $4 \mathrm{~mL}$ incubation mixture. As suggested by the software, 13 experimental runs were conducted in triplicates. The ANOVA analysis data are presented in Tables 1 and 2, where $\mathrm{A}$ and $\mathrm{B}$ are denoted for the concentrations of $\left(\mathrm{NH}_{4}\right)_{2} \mathrm{SO}_{4}$, and GA, respectively. The model regression equations to describe the optimum preparation for both are given as Equations 4 and 5. These regression equations can be applied to investigate the interaction between variables. The optimum level determination of each factor for maximum lipase residual activity can be graphically represented by $3 \mathrm{D}$ response surface plots, given by

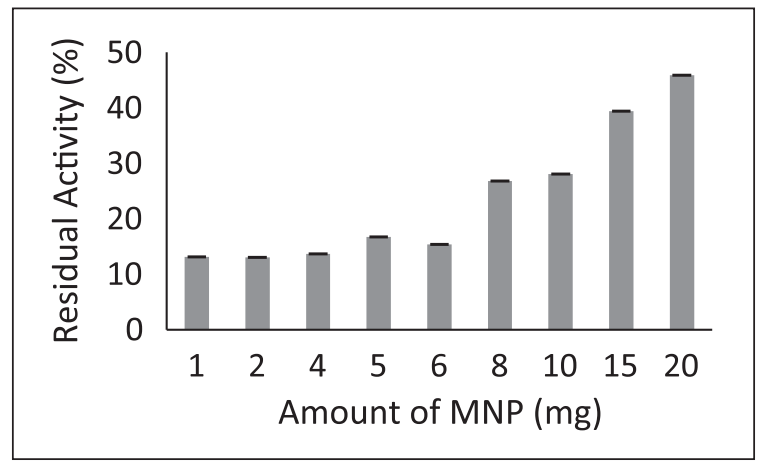

Fig. 1. Effect of amount of MNPs on lipase residual activity of MNP-CLEA-lipase.

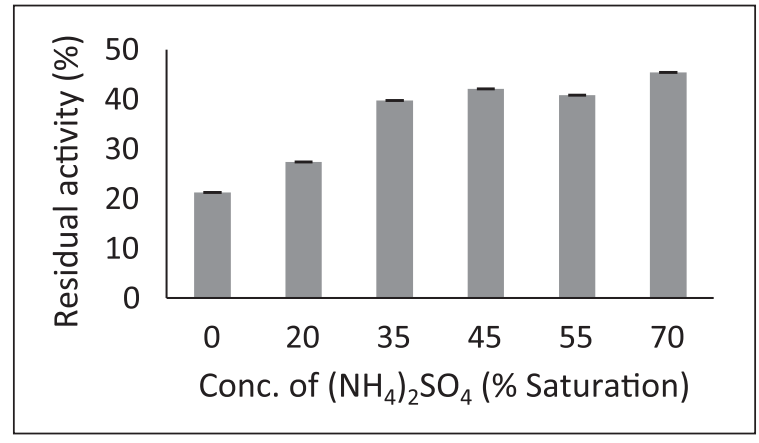

Fig. 2. Effect of concentration of $\left(\mathrm{NH}_{4}\right)_{2} \mathrm{SO}_{4}$ (\% Saturation) on lipase residual activity of MNP-CLEA-lipase.

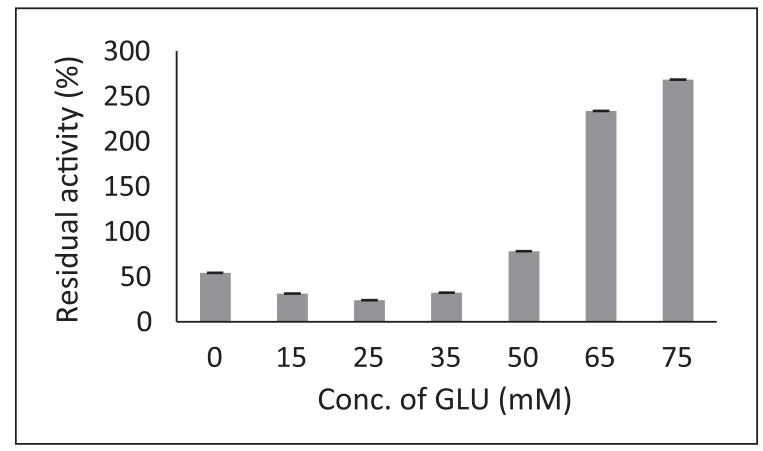

Fig. 3. Effect of concentration of GA on lipase residual activity of MNP-CLEA-lipase.

Figure 3 and 4, that showed the level of interaction between the two variables. Based on the value of coefficient determinants, $\mathrm{R}^{2}$, regression equation for CLEA-lipase with $\mathrm{R}^{2}=0.6771$, fitted better than the regression equation for MNP-CLEA-lipase, with $\mathrm{R}^{2}=0.6269$.

Unfortunately, both model equations were not significant.

$$
\begin{array}{rlr}
Y(C L)= & 21.12+2.35 A-0.13 B-2.70 A^{2} \quad \text { Eq. (4) } \\
- & 3.20 B^{2}-1.27 A B \\
Y(M C L)= & 83.23+1.96 A-8.68 B+4.80 A^{2} \quad \text { Eq. (5) } \\
& -9.53 B^{2}-0.40 A B &
\end{array}
$$


Table 1. ANOVA for CLEA-lipase experimental runs

\begin{tabular}{|c|c|c|c|c|c|c|}
\hline Source & Sum of Square & DF & Mean Squares & $\mathrm{F}$ value & Prob $>F$ & \\
\hline Model & 117.72 & 5 & 23.54 & 2.94 & 0.0964 & Not significant \\
\hline A & 33.27 & 1 & 33.27 & 4.15 & 0.0811 & \\
\hline $\mathrm{B}$ & 0.094 & 1 & 0.094 & 0.012 & 0.9168 & \\
\hline $\mathrm{A}^{2}$ & 20.08 & 1 & 20.08 & 2.50 & 0.1576 & \\
\hline $\mathrm{B}^{2}$ & 28.37 & 1 & 28.37 & 3.54 & 0.1021 & \\
\hline$A B$ & 6.41 & 1 & 6.41 & 0.80 & 0.4010 & \\
\hline Residual & 56.14 & 7 & 8.02 & & & \\
\hline Lack of Fit & 3.61 & 3 & 1.20 & 0.092 & 0.9608 & Not significant \\
\hline Pure Error & 52.53 & 4 & 13.13 & & & \\
\hline Cor Total & 173.86 & 12 & & & & \\
\hline
\end{tabular}

Table 2. ANOVA for MNP-CLEA-lipase experimental runs

\begin{tabular}{|c|c|c|c|c|c|c|}
\hline Source & Sum of Square & DF & Mean Squares & $F$ value & Prob $>F$ & \\
\hline Model & 730.65 & 5 & 146.13 & 2.35 & 0.1477 & Not significant \\
\hline A & 23.13 & 1 & 23.13 & 0.37 & 0.5611 & \\
\hline B & 451.71 & 1 & 451.71 & 7.27 & 0.0308 & \\
\hline$A^{2}$ & 63.69 & 1 & 63.69 & 1.03 & 0.3450 & \\
\hline$B^{2}$ & 63.69 & 1 & 250.73 & 4.04 & 0.0845 & \\
\hline$A B$ & 0.64 & 1 & 0.64 & 0.010 & 0.9220 & \\
\hline Residual & 434.91 & 7 & 62.13 & & & \\
\hline Lack of Fit & 434.91 & 3 & 144.97 & & & Not significant \\
\hline Pure Error & 0.00 & 4 & 0.00 & & & \\
\hline Cor Total & 1165.55 & 12 & & & & \\
\hline
\end{tabular}

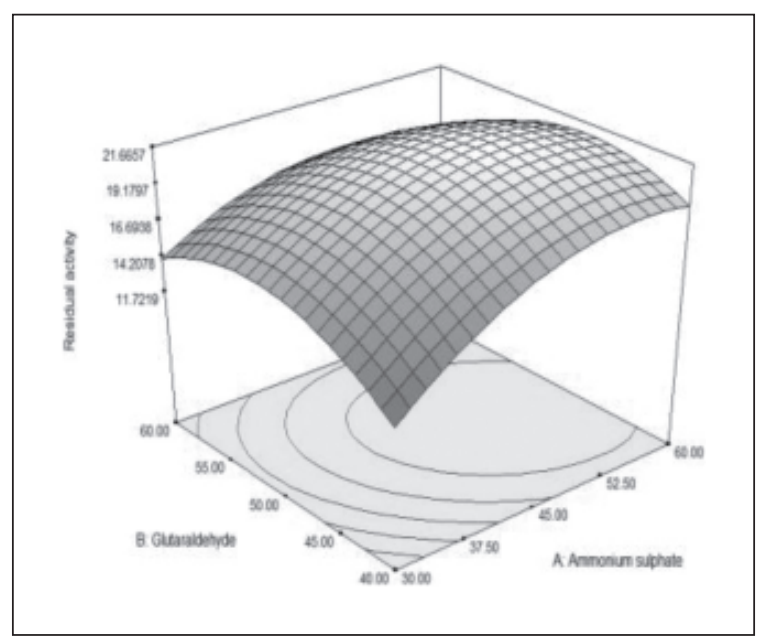

Fig. 4. 3-D response surface plots for CLEA-lipase, Fvalue $=2.94, p=0.0964, R^{2}=0.6771$.

Referring to the above Equations 4 and 5, $Y(C L)$ and $Y(M C L)$ represent the equations obtained for CLEA-lipase and MNP-CLEA-lipase, respectively. From the optimization study conducted, the highest response determined was $24.84 \%$ RA for CLEAlipase by using $45 \%$ saturated $\left(\mathrm{NH}_{4}\right)_{2} \mathrm{SO}_{4}$ and 50 mM GA. On the other hand, MNP-CLEA-lipase achieved the highest at $96.38 \%$ RA by using $70 \%$ saturated $\left(\mathrm{NH}_{4}\right)_{2} \mathrm{SO}_{4}$ and $60 \mathrm{mM} \mathrm{GA}$, which means,

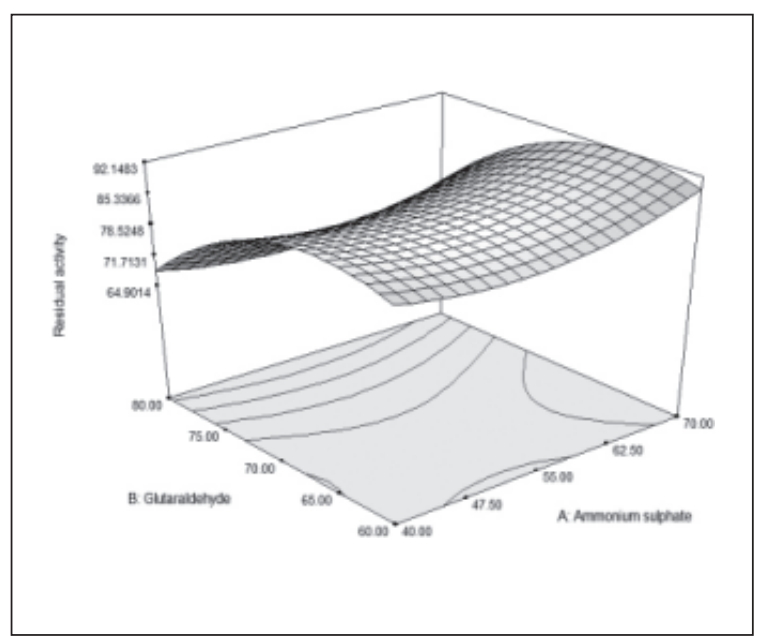

Fig. 5. 3-D response surface plot for MNP-CLEA-lipase, $\mathrm{F}$ value $=2.35, \mathrm{p}=0.0181, \mathrm{R}^{2}=0.6269$.

overall, MNP-CLEA-lipase showed higher \% RA than its unsupported counterpart. The increased in activity can be partly explained by the presence of MNPs. According to Talekar et al. (2012), the addition of amino functionalized MNP into the enzyme solution may increase the amine groups concentration and thus, when the precipitated enzyme and amino functionalized MNP were crosslinked via GA, a higher amount of insoluble and 
active biocatalysts could be formed due to sufficient amount of amine groups.

\section{Effect of temperature and pH on CLEA-lipase and MNP-CLEA-lipase activity}

The results in Figure 6 showed that the best working temperature for both CLEA-lipase and MNP-CLEA-lipase occurred at $35^{\circ} \mathrm{C}$. However, the achievements of the residual activities at this temperature differs; it is much higher for MNPCLEA-lipase whereby the RA was $85.89 \%$ compared to CLEA-lipase, of $31.91 \%$. This is in agreement with Talekar et al. (2012), who suggested that, a higher lipase residual activity can be achieved in MNP-CLEA-lipase, due to the presence of higher amount of covalent cross-linkings between lipase enzyme and amino functionalized MNP. It seems that the formation of higher number of covalent bonds elevate the tolerance of the enzyme against high temperatures.

As for $\mathrm{pH}$, as being shown by Figure 7, the best working $\mathrm{pH}$ of CLEA-lipase changes when it is supported by MNP. The highest lipase residual activity for CLEA-lipase, is $20.66 \%$ at $\mathrm{pH}$ 6, however the best working $\mathrm{pH}$ changed to 8 , when it is supported by MNP, achieving 69.92\% RA. The shift in the best working $\mathrm{pH}$ may be due to the changes in the nature of ionization of the acidic and basic amino acid side chains in the microenvironment around the active site of both types of enzymes. Elevated $\mathrm{pH}$ of 8 was more preferred by the supported CLEA. The presence of the more interactions between the basic residues of enzyme and GA as a results of cross-linking may have allowed the activity of MNP-CLEA-lipase to supresede its unsupported counterparts (Talekar et al., 2012).

\section{Thermal and pH stabilities}

As depicted by Figure 8, in terms of thermal stability, MNP-CLEA-lipase showed to be more stable compared to CLEA-lipase at the tested temperature ranging from 25 to $60^{\circ} \mathrm{C}$. After both were incubated for $30 \mathrm{~min}$ at $60^{\circ} \mathrm{C}$, MNP-CLEAlipase retained $70.09 \%$ RA compared to $32.86 \%$ for CLEA-lipase. The results indicate that MNP-CLEAlipase is more thermally stable compared to CLEAlipase.

The presence of adequate covalent crosslinking between the enzyme molecules and the aminofunctionalized MNP results in better flexibilities in different temperatures and were able to withstand extreme temperature better compared to the unsupported ones (Talekar et al., 2012; Khanahmadi et al., 2015).

For the $\mathrm{pH}$ stability study, as shown by Fig. 9, MNP-CLEA-lipase is more stable in the $\mathrm{pH}$ range of 5-10 compared to CLEA-lipase. At the highest

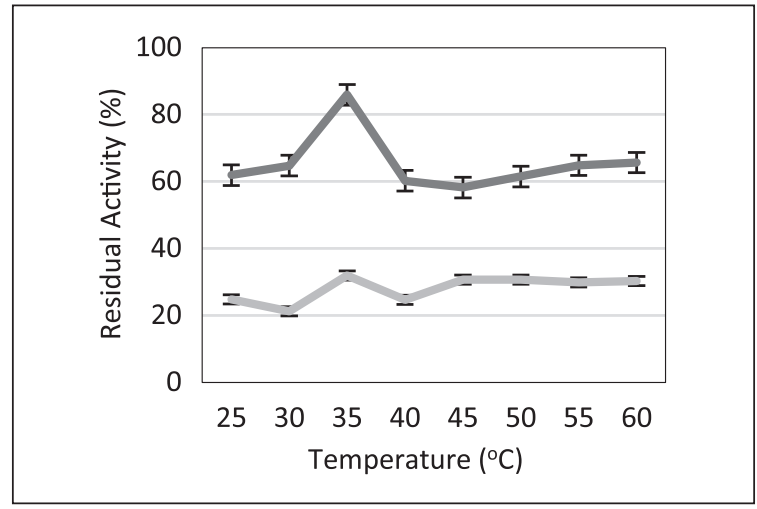

Fig. 6. Effect of temperature on CLEA-lipase - and MNP-CLEA-lipase - .

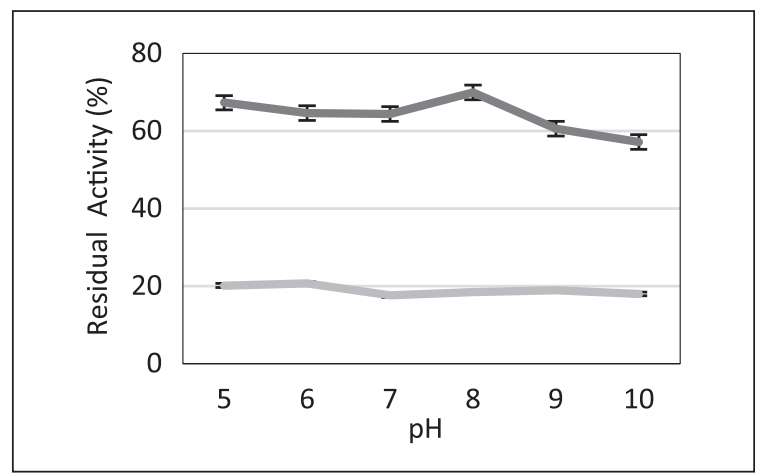

Fig. 7. Effect of pH on CLEA-lipase - and MNPCLEA-lipase $\longrightarrow$.

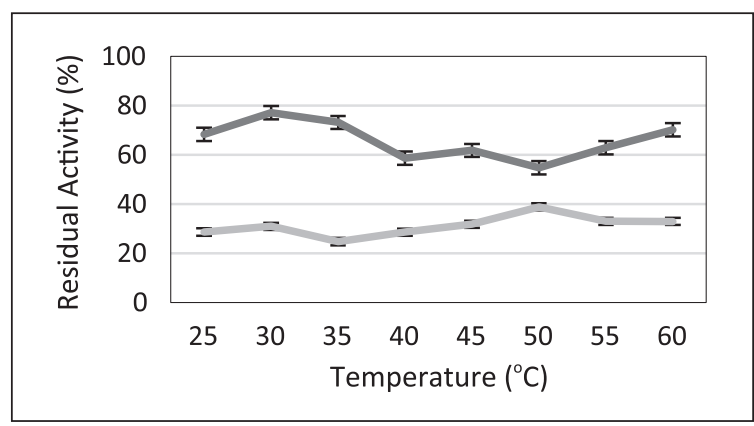

Fig. 8. Thermal stability for CLEA-lipase $-\rightarrow$ and MNPCLEA-lipase $\longrightarrow$.

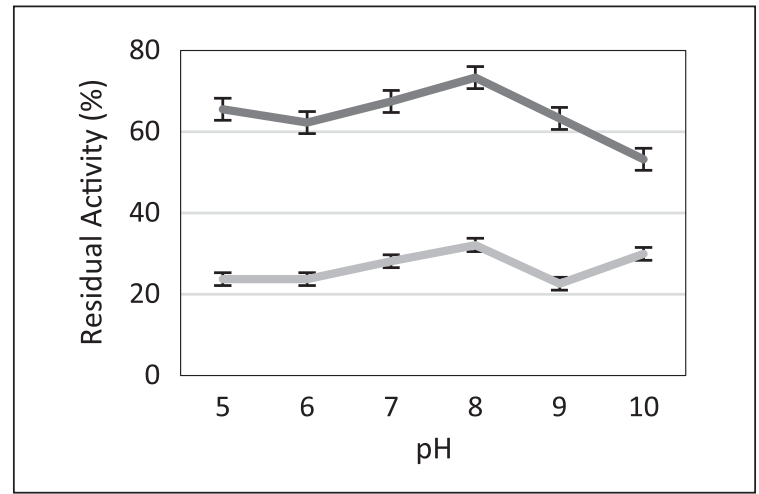

Fig. 9. pH stability for CLEA-lipase $\longrightarrow$ and MNPCLEA-lipase 
achievement at $\mathrm{pH} 8$, MNP-CLEA-lipase retained $73.32 \%$, whereas CLEA-lipase only retained $32.14 \%$ RA.

The resistance to $\mathrm{pH}$ changes of CLEA could be due to the covalent cross-linking throughout enzyme aggregates that may have increased the flexibility of the enzyme in different $\mathrm{pH}$ conditions (Yu et al., 2013; Yusof et al., 2013; Khanahmadi et al., 2015). However, higher resistance towards pH changes was observed in MNP-CLEA-lipase compared to the unsupported counterparts, inferring the availability of more sufficient covalent crosslinkings.

\section{Reusability}

Immobilized enzymes should be highly stable to enable its reusability (Mateo et al., 2007; Khanahmadi et al., 2015). The enzymes can be reusable only if it can retain its activity after several cycles (Garcia-Galan et al., 2011). In this research, reusability of CLEA-lipase was studied by carrying out the enzyme activity up to six cycles. Based on the results shown in Figure 10, CLEA-lipase retained $53.13 \%$ of the first time activity (considered as $100 \%$ ) after six cycles while MNP-CLEA-lipase retained $56.46 \%$. By comparison, their loss of enzyme activity during the six cycles followed the same trend, however, there was a slight enhancement for the supported CLEA. This loss may be due to the leaching of enzymes in the reaction medium during the process of washings, which is caused by inefficient cross-linking of the enzymes. On the other hand, adequate cross-linking of lipase and the amino functionalized MNPs enabled it to retain higher activity even after six cycles.

\section{Morphological analysis by FESEM}

Figure 11 showed the FESEM micrographs of functionalized MNPs before it was used as supports to CLEA-lipase. Due to its magnetic properties, the molecules are seen to form spheres, and with closer inspection the spheres appeared to be loosely aggregated. The estimated sizes for each sphere is about $20 \mathrm{~nm}$.

The FESEM micrographs of MNP-CLEA-lipase is shown by Figure 12. According to Shoevaart et al. (2004), the appearance of CLEAs are either a compact spherical shape (Type 1) or less-structured (Type 2). Both have bearings towards the activity of enzymes, which relates to mass transfer limitations. In this research, MNP-CLEA-lipase produced appeared as Type 2, which is loosely structured, as shown by Figure 12.

Loosely structured means the structure were less compact, and this leads to lesser resistance to mass transfer (Yusof et al., 2016). This is especially important for larger substrates, for easy accessibility to the active sites of the enzyme. In

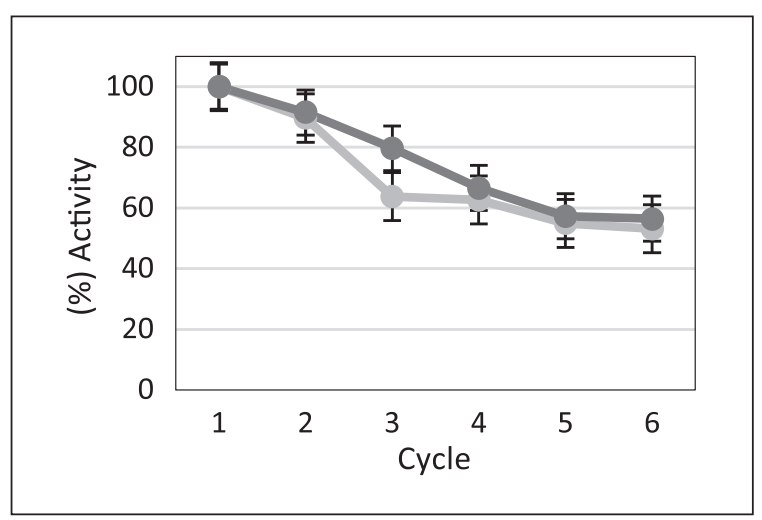

Fig. 10. Reusability of CLEA-lipase - and MNPCLEA-lipase $\longrightarrow$.

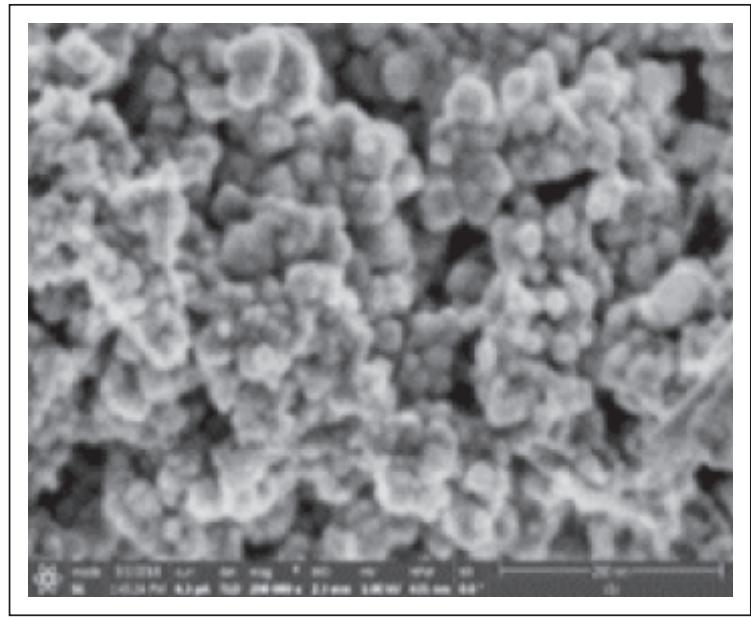

Fig. 11. FESEM for non-functionalized MNPs.

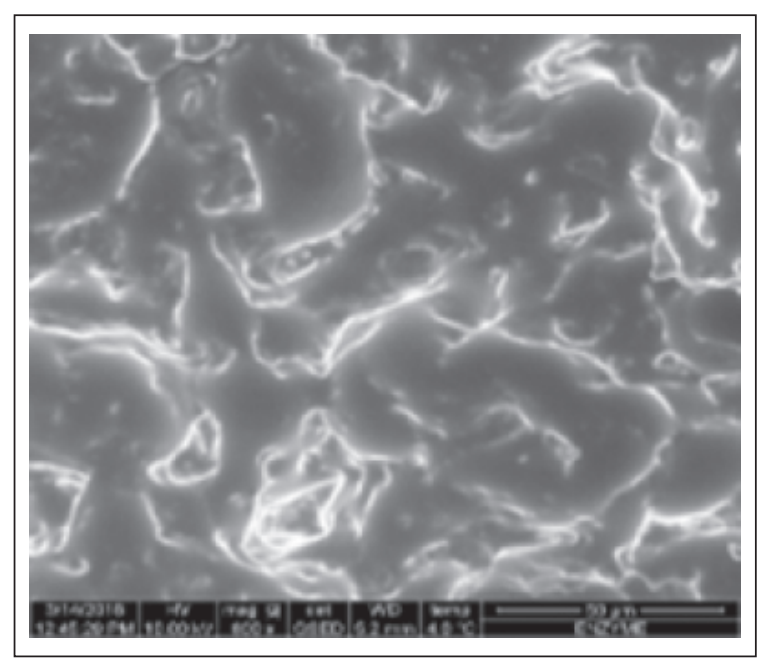

Fig. 12. FESEM for MNP-CLEA-lipase.

this research, pNPP was used as the substrate for the lipase activity. pNPP is a big molecule, having 18 carbons as its hydrophobic tail. Loosely structured biocatalyst will ease the manuevaring of this substrate molecules towards the enzyme's active-sites. According to $\mathrm{Yu}$ et al. (2006) and 


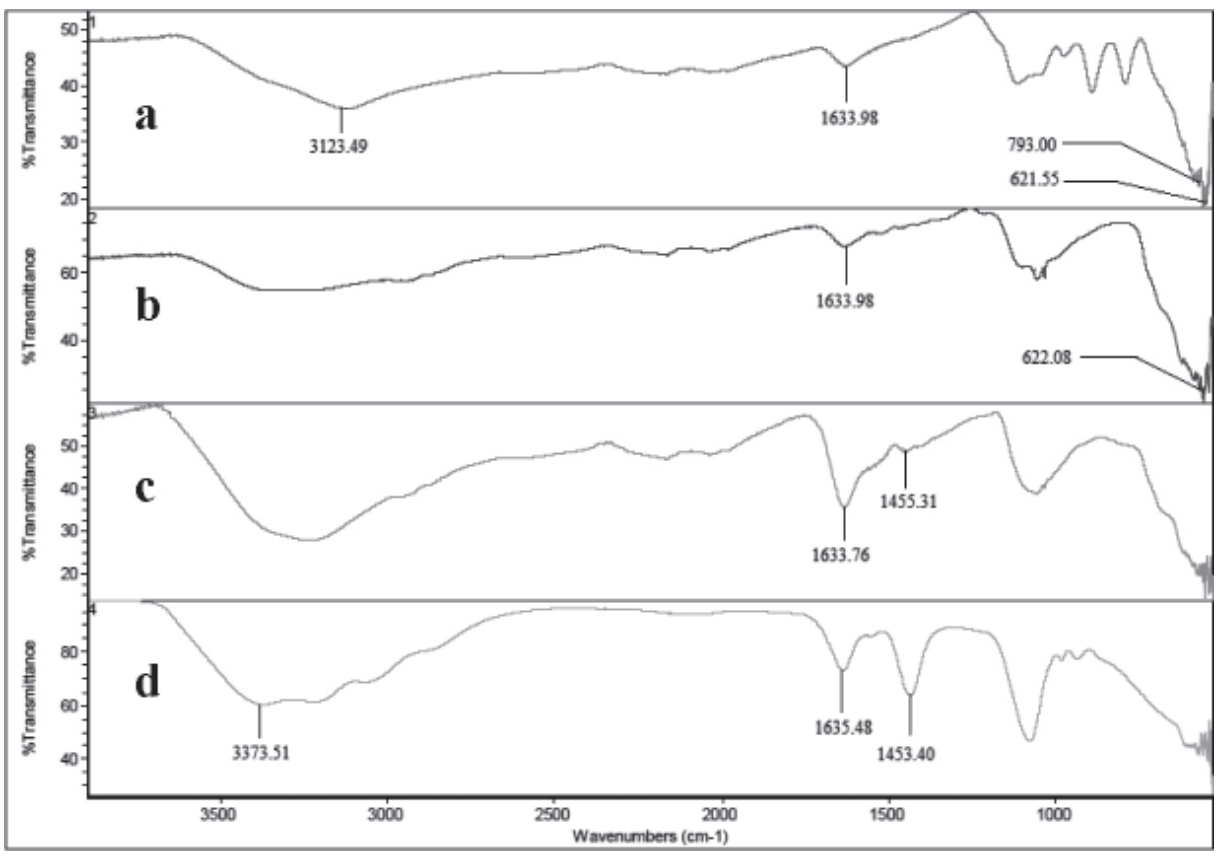

Fig. 13. FTIR analysis (a) non-functionalized MNPs, (b) functionalized MNPs, (c) MNP-CLEAlipase, (d) free-lipase.

Sheldon (2019), the morphological appearances and the particle sizes of CLEA are also influenced by other parameters such as the concentrations of enzymes, the types of precipitants, cross-linkers and additives. On the other hand, particle sizes of CLEA also affect filterability, especially in the nonmagnetic system. Sheldon (2019) emphasized that the molar ratio of cross-linker to enzyme influences the activity, stability and the particle size of the resulting CLEA. Other important factors that influence the recovery activity as well as the particle size and morphology of CLEA are the rate of addition of the cross-linker and the cross-linking time. Pchelintsev et al. (2009) reported that the particle size of a CLEA can also increase on ageing, which suggest that the cross-linking process may not have been completed.

\section{Structural characterisation by FTIR}

FTIR spectroscopy analyzes the samples by providing information on the structural features of molecules. It also allows us to determine the presence of functional groups and bonds of each sample based on peak values at the designated wavelengths (Fabian \& Mantele, 2002).

Figure 13 shows the FTIR comparison spectra for MNPs, functionalized MNPs, MNP-CLEA-lipase and free lipase. Figure 13 (a) shows a typical FTIR spectrum of $\mathrm{Fe}_{3} \mathrm{O}_{4}$ containing magnetite. The spectrum contains characteristic bands of the $\mathrm{Fe}-\mathrm{O}$ at around in $621 \mathrm{~cm}^{-1}$. When functionalized by APTES, the FTIR spectrum of the magnetite shifted to higher wavenumbers, to account for the presence of $\mathrm{Fe}-\mathrm{O}-\mathrm{Si}$ bonds as shown in Figure 13 (b). This is because, once functionalized, the $\mathrm{Fe}-\mathrm{O}-\mathrm{H}$ groups on the surface of magnetite were replaced by $\mathrm{Fe}-\mathrm{O}-\mathrm{Si}(\mathrm{O}-)_{2}-\mathrm{R}$. The higher electronegativity of $-\mathrm{Si}(\mathrm{O}-)$ compared to $\mathrm{H}$ leads to an enhancement of the bond forces for the $\mathrm{Fe}-\mathrm{O}$ bonds, shifting the absorption bands to high wave numbers (Ma et al., 2003). Results also showed that, once CLEA-lipase was immobilized on the MNP, the FTIR spectrum of the immobilized biocatalyst appeared quite similar to its corresponding enzymes [compare Figure 13 (c) for MNP-CLEA-lipase with Figure 13 (d) for free lipase]. The presence of a more pronounced broad peak around $3373 \mathrm{~cm}^{-1}$ corresponding to the $\mathrm{N}-\mathrm{H}$ asymmetric stretching is contributed by amine $\mathrm{H}$-bonds. The presence of new peaks in the immobilized biocatalyst, at wavelength $1633 \mathrm{~cm}^{-1}$ are ascribed to Amide $\mathrm{I}(\mathrm{C}=\mathrm{O}$ stretching) and, at $1455 \mathrm{~cm}^{-1}$, to Amide II (CN stretching and $\mathrm{NH}$ bending). In general, the spectra in Figure 13 showed that MNP has been successfully functionalized by APTES and finally cross-linked to CLEA-lipase via GA.

\section{CONCLUSION}

In conclusion, the management of waste from the rubber manufacturing industry problem can be partly solved by utilizing the skim latex to produce important biocatalysts. Skim latex, a byproduct of 
the high concentrated latex industry, instead of being thrown away, can be value-added by recovering an important enzyme such as lipase. Lipase was chosen because of its versatility and wide use in industrial applications. However, the use of free lipase suffers from many disadvantages, in terms of stability. It has been shown that the activity of lipase can be enhanced by immobilization by CLEA technology, and in the present research, it is shown that it can be further enhanced by use of MNPs support. The optimum process conditions to prepare MNP-CLEA-lipase and CLEA-lipase for maximal enzyme activity differs in terms of the concentrations of precipitant and cross-linker used. Overall, MNP-CLEA-lipase was shown to perform better in many aspects compared to the unsupported one; it is more stable at high temperature and at more extreme pHs. This is especially important if these biocatalyst are intended to be used in the industrial settings, whereby the temperature and $\mathrm{pH}$ of reactions can shift to the extremes during the processes. Upon testing, MNP-CLEA-lipase was able to be recycled as much as six times, retaining higher residual activity than its unsupported counterpart. Separation of the magnetic biocatalyst from the reaction media was made easy, by using magnetic field, instead of the cumbersome centrifugation and filtration processes for the unsupported CLEA. The FESEM results showed that the MNP-CLEA-lipase is a Type 2, which is less structured, and this may be an advantage because it leads to less resistance towards mass transfer during the enzymatic reaction. FTIR showed that MNP-CLEA-lipase was successfully produced, proven by the increased presence of Amide I and Amide II bands, that represents the increase of amide bonds in the new biocatalyst. Overall, the production of value-added products from skim latex such as MNP-CLEA-lipase with enhanced properties, demonstrated that the wasteful byproducts could easily be converted to innovative biomaterial, which has potential to be used in many biotechnological applications.

\section{ACKNOWLEDGMENT}

The authors would like to acknowledge the Department of Biotechnology Engineering, Kulliyyah of Engineering, International Islamic University Malaysia (IIUM) for providing the laboratory facilities to carry out this research.

\section{REFERENCES}

Abdelmoez, W., Mostafa, N. \& Mustafa, A. 2013. Utilization of oleochemical industry residues as substrates for lipase production for enzymatic sunflower oil hydrolysis. J Clean Prod., 59: 290-297.

Ansari, S.A. \& Husain, Q. 2012. Potential applications of enzymes immobilized on/in nano materials: A review. Biotechnology Advances, 30(3): 512-523.

Aravindan, R., Anbumathi, P. \& Viruthagiri, T. 2007. Lipase applications in food industry. Indian $J$ Biotechnol, 6: 141-158.

Barbosa, O., Ortiz, C., Berenguer-Murcia, Á., Torres, R., Rodrigues, R.C. \& Fernandez-Lafuente, R. 2014. Glutaraldehyde in biocatalysts design: A useful crosslinker and a versatile tool in enzyme immobilization. RSC Adv., 4: 1583-1600.

Bhattacharya, A. \& Pletschke, B.I. 2014. Magnetic cross-linked enzyme aggregates (CLEAs): A novel concept towards carrier free immobilization of lignocellulolytic enzymes. Enzyme and Microbial Technology, 61-62: 17-27.

Bio-Rad Laboratories. 2010. Bio-Rad protein assay. Bio-Rad, 1-24.

Bradford, M. (1976). A rapid and sensitive method for the quantitation of microgram quantities of protein utilizing the principle of protein-dye binding, Analytical Biochemistry, 72(1-2): 248254.

Brady, D. \& Jordaan, J. (2009). Advances in enzyme immobilization. Biotechnology Letters, 31: 1639-1650.

Cataldo, F. (2000). Guayule rubber: a new possible world scenario for the production of natural rubber. Prog. Rubber Plast. Technol., 16: 31-59.

Chen, J.C. \& Tsai, S.W. 2000. Enantioselective synthesis of (S)-Ibuprofen ester prodrug in cyclohexane by Candida rugosa lipase immobilized on Accurel MP1000. Biotechnol Prog., 16: 986-992.

Dussán, K., Giraldo, O. \& Cardona, C. 2007. Application of magnetic nanostructures in biotechnological processes: Biodiesel production using lipase immobilized on magnetic carriers. In: Proceedings of the European Congress of Chemical Engineering, 1-7.

Easa, M.N. \& Yusof, F. 2015. Optimizing the preparation of cross-linked enzyme aggregates (CLEA)-amylase from supermeal worm (Zophobas morio). ARPN Journal of Engineering and Applied Sciences, 10(21): 9710-9716. 
Elkady, M., Hassan, H.S. \& Hashim, A. 2016. Immobilization of magnetic nanoparticles onto amine-modified nano-silica gel for copper Ions Remediation, Materials, 9: 460.

Emtenani, S., Asoodeh, A. \& Emtenani, S. 2013. Molecular cloning of a thermo-alkaliphilic lipase from Bacillus subtilis DR8806: Expression and biochemical characterisation. Process Biochem, 48: 1679-1685.

Fabian, H. \& Mäntele, W. 2002. Infrared spectroscopy of proteins. Handbook of Vibrational Spectroscopy, 5: 3426-3452.

Garcia-Galan, C., Berenguer-Murcia, Á., FernandezLafuente, R. \& Rodrigues, R.C. 2011. Potential of different enzyme immobilization strategies to improve enzyme performance. Advanced Synthesis and Catalysis, 353(16): 2885-2904.

George, K.M., Alex, R., Joseph, S. \& Thomas, K.T. 2009. Characterisation of enzyme-deproteinized skim rubber, Journal of Applied Polymer Science, 114(5): 3319-3324.

Gotor-Fernández, V., Brieva, R. \& Gotor, V. 2006. Lipases: useful biocatalysts for the preparation of pharmaceuticals. J Mol CatalB Enzym, 40: 111-1204.

Gupta, A. \& Srivastava, S.K. (2017). Study of cross linked enzyme aggregate of glucose isomerase of Streptomyces thermonitrificans immoblised on magnetic particle. Journal of Biochemical Technology, 7(1): 1102-1106.

Gupta, K., Jana, A.K., Kumar, S. \& Maiti, M. 2013a. Immobilization of $\alpha$-amylase and amyloglucosidase onto ion-exchange resin beads and hydrolysis of natural starch at high concentration. Bioprocess and Biosystems Engineering 36(11): 1715-1724.

Gupta, K., Jana, A.K., Kumar, S. \& Maiti, M. 2013 b. Immobilization of amyloglucosidase from SSF of Aspergillus niger by crosslinked enzyme aggregate onto magnetic nanoparticles using minimum amount of carrier and characterisations. Journal of Molecular Catalysis B: Enzymatic, 98: 30-36.

Hasan, F., Shah, A.A., Javed, S. \& Hameed, A. 2013. Enzymes used in detergents: lipases. African Journal of Biotechnol, 9: 4836-4844.

Khanahmadi, S., Yusof, F., Amid, A. \& Mahat, M.K. 2015. Optimized preparation and characterisation of CLEA-lipase from Cocoa Pod Husk, Journal of Biotechnology, 202: 153-161.

Khoshnevisan, K., Vakhshiteh, F., Barkhi, M., Baharifar, H., Akbar, E.P., Zari, N., Stamatis, H. \& Abdol-Khalegh Bordbar, A.K. 2017. Immobilization of cellulase enzyme onto magnetic nanoparticles: Applications and recent advances, Molecular Catalysis, 442: 66-73.
Ma, M., Zhang, Y., Yu, W., Shen, H.Y., Zhang, H.Q. \& Gu, N. (2003). Preparation and characterisation of magnetite nanoparticles coated by amino silane. Colloids and Surfaces APhysicochemical and Engineering Aspects, 212(2-3): 219-226.

Mahmod, S.S., Yusof, F., Jami, M.S. \& Khanahmadi, S. 2016. Optimizing the preparation conditions and characterisation of a stable and recyclable cross-linked enzyme aggregate (CLEA)protease. Bioresources and Bioprocessing, 3(3): $1-11$.

Mahmod, S.S., Yusof, F., Jami, M.S., Khanahmadi, S. \& Shah, H. 2015. Development of an immobilized biocatalyst with lipase and protease activities as a multipurpose cross-linked enzyme aggregate (multi-CLEA). Process Biochemistry, 50(12): 2144-2157.

Mardina, V. \& Yusof, F. 2018. Skim latex serum as an alternative nutrition for microbial growth. In: Multifaceted Protocol in Biotechnology (Amid et al, Eds.), 79-196, Springer Nature, Singapore.

Mateo, C., Palomo, J.M., Fernandez-Lorente, G., Guisan, J.M. \& Fernandez-Lafuente, R. 2007. Improvement of enzyme activity, stability and selectivity via immobilization techniques. Enzym. Microb. Technol., 40(6): 1451-1463.

Mohamed, N. \& Yusof, F. (2014). Experimental Design and Statistical Analysis of Protein Buffer to Purify Hydrolases from the Skim Latex of Hevea brasiliensis. Advances in Environmental Biology, 8(3): 672-679.

Mohammadi, M., Man, H., Hassan, M. \& Yee, P. 2013. Treatment of wastewater from rubber industry in Malaysia. African Journal of Biotechnology, 9(38): 6233-6243.

Pchelintsev, N.A., Youshko, M.I. \& Svedas, V.K. 2009. Quantitative characteristic of the catalytic properties and microstructure of cross-linked enzyme aggregates of penicillin acylase. J. Mol. Catal. B Enzym., 56: 202-207.

Raita, M., Champreda, V. \& Laosiripojana, N. 2010. Biocatalytic ethanolysis of palm oil for biodiesel production using microcrystalline lipase in tert-butanol system. Process Biochem, 45: 829-834.

Rathi, P., Saxena, R. \& Gupta, R. 2001. A novel alkaline lipase from Burkholderia cepacia for detergent formulation. Process, 37: 187-192.

Rattanaphan, O., Danwanichakul, D. \& Danwanichakul, P. 2012. Reduction of protein content in skim rubber via both extractions in skim latex and from rubber films. $1^{\text {st }}$ Mae Fah Luang University International Conference, 1-7. 
Reza, R.T., Pérez, C.A.M., González, C.A.R., Romero, H.M. \& Casillas, P.E.G. 2010. Effect of the polymeric coating over $\mathrm{Fe}_{3} \mathrm{O}_{4}$ particles used for magnetic separation, 8(5): 1041-1046.

Roessl, U., Nahálka, J. \& Nidetzky, B. 2010. Carrierfree immobilized enzymes for biocatalysis. Biotechnology Letters, 32(3): 341-350.

Sarkar, P., Yamasaki, S., Basak, S., Bera, A. \& Bag, P.K. 2012. Purification and characterisation of a new alkali-thermostable lipase from Staphylococcus aureus isolated from Arachis hypogaea rhizosphere. Process Biochem, 47: 858-866.

Schoevaart, R., Wolbers, M., Golubovic, M., Ottens, M., Kieboom, A., Van Rantwijk, F. \& Sheldon, R.A. 2004. Preparation, optimization, and structures of crosslinked enzyme aggregates (CLEAs). Biotechnology and Bioengineering, 87(6): 754-762.

Sheldon, R.A. \& Van Pelt, S. (2013). Enzyme immobilisation in biocatalysis: why, what and how. Chemical Society Reviews, 42(42): 62236235.

Sheldon, R.A. 2007a. Enzyme immobilisation: the quest for optimum performance. Adv Synth Catal, 349: 1289-1307.

Sheldon, R.A. 2007b. Cross-linked enzyme aggregates (CLEAs): stable and recyclable biocatalysts. Biochem Soc Trans, 35: 15831587.

Sheldon, R.A. 2011. Characteristic features and biotechnological applications of cross-linked enzyme aggregates (CLEAs). Applied Microbiology and Biotechnology, 92(3): 467-477.

Sheldon, R.A. 2019. CLEAs, Combi-CLEAs and 'Smart' Magnetic CLEAs: Biocatlysis in a BioBased Economy, Catalysts, 9: 261.

Stergiou, P.Y., Foukis, A., Filippou, M., Koukouritaki, M., Parapouli, M., Theodorou, L.G., Hatziloukas, E., Afendra, A., Pandey, A. \& Papamichael, E.M. 2013. Advances in lipasecatalyzed esterification reactions. Biotechnol $A d v ., 31$ : 1846-1859.
Talekar, S.J. 2013. Parameters in preparation and characterisation of cross-linked enzyme aggregates (CLEAs). Rsc Advances, 3(31): 12485-12511.

Talekar, S.J., Ghodake, V., Ghotage, T., Rathod, P., Deshmukh, P., Nadar, S. \& Ladole, M. 2012. Novel magnetic cross-linked enzyme aggregates (magnetic CLEAs) of alpha amylase. Bioresource Technology, 123: 542-547.

Undurraga, D., Markovits, A. \& Erazo, S. 2001. Cocoa butter equivalent through enzymic interesterification of palm oil mid-fraction. Process Biochem, 36: 933-939.

Xin, J.Y., Li, S.B., Xu, Y., Chui, J.R. \& Xia, C.G. 2001. Dynamic enzymatic resolution of naproxen methyl ester in a membrane bioreactor. J Chem Technol Biotechnol., 76: 579-585.

Yu, C.Y., Li, X.F., Lou, W.Y. \& Zong, M.H. 2013. Cross-linked enzyme aggregates of mung bean epoxide hydrolases: a highly active, stable and recyclable biocatalyst for asymmetric hydrolysis of epoxides. J. Biotechnol., 166(1): 12-19.

Yu, H.W., Chen, H., Wang, X., Yang, Y.Y. \& Ching, C.B. 2006. Cross-linked enzyme aggregates (CLEAs) with controlled particles: Application to Candida rugosa lipase. Journal of Molecular Catalysis B: Enzymatic, 43(1-4): 124-127.

Yusof, F., Abd Aziz, M.R.F. \& Jimat, D.N. 2013. Preparation of cross-linked enzyme aggregate (CLEA)-lipase from skim latex serum of Hevea brasiliensis. Proceedings of International Conference on Biotechnology Engineering (ICBioE 2013), Kuala Lumpur, 355-359, ISBN: 978-983-42978-6-2.

Yusof, F., Khanahmadi, S., Amid, A. \& Mahmod, S.S. 2016. Cocoa pod husk, a new source of hydrolase enzymes for preparation of crosslinked enzyme aggregate. Springer Plus, 5(57): 1-18.

Yusof, F., Ward, M.A. \& Walker, J.M. 1998. Purification and characterisation of an inhibitor of rubber biosynthesis from C-serum of Hevea brasiliensis latex, Journal of Rubber Research, 1(2): 95-110. 